\title{
KAJIAN PENGARUH KEMIRINGAN RANGKA BATANG RASUK PARALEL TERHADAP LENDUTAN
}

\author{
Ginardy Husada ${ }^{1}$, Kanjalia Tjandrapuspa Tanamal $^{2}$ \\ ${ }^{1,2}$ Dosen Jurusan Teknik Sipil, Fakultas Teknik, Universitas Kristen Maranatha \\ Email: betaagin@yahoo.com
}

\begin{abstract}
ABSTRAK
Perencanaan Rangka batang merupakan bagian dari struktur yang sering kita jumpai, banyak digunakan untuk rangka atap, rangka jembatan, portal dengan bentang besar dan untuk menggantikan balok dengan bentang besar sering memakai rangka batang. Umumnya kemiringan rangka batang sering kita abaikan, apalagi jika dihubungkan dengan lendutan, karena kita menganggap lendutan pada rangka batang seperti balok adalah fungsi momen sehingga kemiringan atap dianggap tidak mempengaruhi lendutan. Dalam kajian ini dicoba 5 model rangka batang rasuk paralel dengan panjang $6 \times 200 \mathrm{~cm}$ dan tinggi rangka $150 \mathrm{~cm}$, tiap model dengan kemiringan $0^{\circ}$, $5^{\circ}, 15^{\circ}, 30^{\circ}$ dan $45^{\circ}$. Dengan beban hidup terpusat $=2000 \mathrm{~kg}$ pada semua titik buhul atas. Hasil dari kajian ini untuk kondisi datar maupun kondisi miring, lendutan yang paling kecil adalah bentuk rangka model 5 dengan hasil lendutan tengan bentang atau titik 4 pada kondisi datar lendutannya $=0,9259 \mathrm{~cm}$. sedangkan untuk kondisi kemiringan sekitar $5^{\circ}$ bentuk rangka yang paling baik adalah model 2 dan model 4 karena lendutannya di titik 4 lebih kecil dari kondisi datar, model 2 dengan lendutan $=1,2119 \mathrm{~cm}$, kondisi datar $=1,2167 \mathrm{~cm}$ dan model 4 dengan lendutan $=$ $1,2583 \mathrm{~cm}$, kondisi datar $=1,2994 \mathrm{~cm}$, dan hasil lainnya dengan bertambahnya kemiringan umumnya lendutan juga bertambah. Jadi untuk rangka batang lendutannya tidak mengikuti fungsi Momen.
\end{abstract}

Kata Kunci: Rangka Batang, Lendutan.

\section{PENDAHULUAN}

Rangka batang umum digunakan untuk rangka atap, jembatan, menganti balok atau portal dengan bentang besar memakai rangka batang. Lendutan pada rangka batang sering dikaitkan dengan lendutan pada balok, dimana pada balok lendutan merupakan fungsi dari momen, sehingga lendutan pada rangka batang diasumsikan seperti fungsi momen, rangka batang dengan bentuk, bentang dan pembebanan sama dengan adanya kemiringan atau tidak adanya kemiringan akan menghasilkan lendutan yang sama.

Dalam kajian ini akan dicoba 5 model rangka batang dengan kemiringan $0^{\circ}, 5^{\circ}$, $15^{\circ}, 30^{\circ}$ dan $45^{\circ}$ dari rangka batang sejenis dengan Beban pada titik kumpul atas dan hasil dari kajian ini akan ditampilkan dalam suatu grafik kemiringan dan lendutan sehingga bisa dilihat dengan jelas pengaruhnya.

Ruang lingkup kajian dibatasi sebagai berikut :

1. Rangka batang Rasuk Paralel dengan bentuk 5 model yang berbeda.

2. Perletakan rangka sendi - rol.

3. Beban yang bekerja terpusat di tiap titik buhul atas sebesar $2000 \mathrm{Kg}$ sama untuk tiap model rangka.

4. Tiap model rangka akan diberi kemiringan dari $0^{\circ}, 5^{\circ}, 15^{\circ}, 30^{\circ}$ dan $45^{\circ}$. 
5. Dimensi batang tepi L 90.90.9 dan dimensi batang tegak dan miring L 60.60.6 sama untuk tiap model rangka.

6. Software yang digunakan Sans ver 4.7 Full Version Licensee Fakultas Teknik Jurusan Sipil Universitas Kristen Maranatha. Bandung.

\section{TINJAUAN PUSTAKA}

\section{Rangka Batang}

Rangka batang merupakan perkembangan dari balok, karena bentang yang cukup besar sehingga tidak memungkinkan memakai balok biasa karena dimensi baloknya akan besar sekali dan berat sendirinya akan besar pula untuk menghindarkan dimensi yang terlalu besar maka dicari alternatif lain, salah satunya dibuat rangka batang dengan ukuran dimensi balok yang kecil, bisa dipakai untuk bentang yang cukup besar dan mampu menahan beban yang besar.

\section{Garis Lentur Balok}

Garis Lentur pada balok merupakan peralihan ordinat suatu titik pada balok terhadap tempat kedudukan awal dari titik tersebut. Pada balok biasa lendutan merupakan fungsi dari Momen sehingga didapat persamaan :

$$
\begin{aligned}
& E I \frac{d^{2} y}{d x^{2}}=-M_{x} \\
& \text { EI } \frac{d y}{d x}=E I \Phi=-\int_{0}^{x} M_{x} d x \\
& E I y=-\iint_{0}^{x} M_{x} d x
\end{aligned}
$$

Dimana :

$$
\begin{array}{lll}
\mathrm{E} & : & \text { Modulus kenyal }\left(\mathrm{Kg} / \mathrm{cm}^{2}\right) \\
\mathrm{I} & : & \text { Momen Inersia }\left(\mathrm{cm}^{4}\right) \\
\mathrm{M}_{\mathrm{x}} & : & \text { Momen, fungsi dari x }(\mathrm{Kg} \mathrm{cm}) \\
\mathrm{y} & : & \text { Peralihan titik }(\mathrm{cm})
\end{array}
$$

\section{Garis Lentur Rangka Batang}

Garis Lentur pada rangka betang dipengaruhi akibat perubahan panjang dan putaran sudut dari rangkaian batang tersebut.Dimana perubahan Panjang batang bisa ditulis dengan persamaan : 


$$
\Delta \mathbf{L}=\frac{\mathbf{S}}{\mathbf{E F}} \cdot \mathbf{L}
$$

$\mathbf{E F} \Delta \mathbf{L}=\mathbf{S} . \mathbf{L}$

Dimana :

$$
\begin{array}{lll}
\mathrm{E} & : & \text { Modulus kenyal }\left(\mathrm{Kg} / \mathrm{cm}^{2}\right) \\
\mathrm{F} & : & \text { Luas Penampang }\left(\mathrm{cm}^{2}\right) \\
\mathrm{S} & : & \text { Gaya batang }(\mathrm{Kg}) \\
\mathrm{L} & : & \text { Panjang Batang }(\mathrm{cm})
\end{array}
$$

\section{DESAIN RANGKA}

\section{Data Rangka Batang}

Data Rangka dalam kajian ini sebagai berikut :

$\begin{array}{lll}\text { Bentang Rangka } & : & 1200 \mathrm{~cm} \\ \text { Segmen Rangka } & : & 200 \mathrm{~cm} \\ \text { Tinggi Rangka } & : & 150 \mathrm{~cm} \\ \text { Beban Terpusat } & : & 2000 \mathrm{Kg} \\ \text { Batang Tepi } & : & \text { Baja L } 90.90 .9 \\ \text { Batang Dalam } & : & \text { Baja L } 60.60 .6 \\ \text { Modulus Elastisitas } & : & 2,1 \times 10^{6}\left(\mathrm{Kg} / \mathrm{cm}^{2}\right)\end{array}$

\section{Model Rangka Batang dan Pembebanan}

Model Rangka Batang Rasuk Paralel dan Pembebanan dalam kajian ini sebagai berikut :

1. Rasuk V (1) dengan Tiang

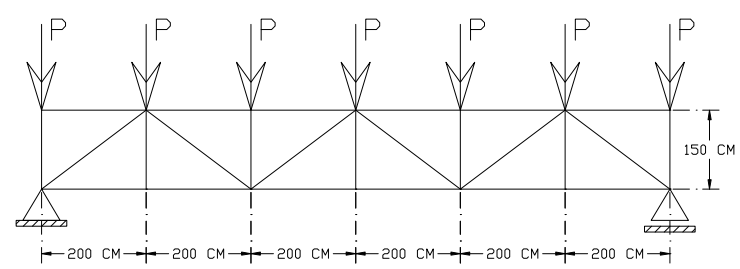

2. Rasuk V (2) dengan Tiang

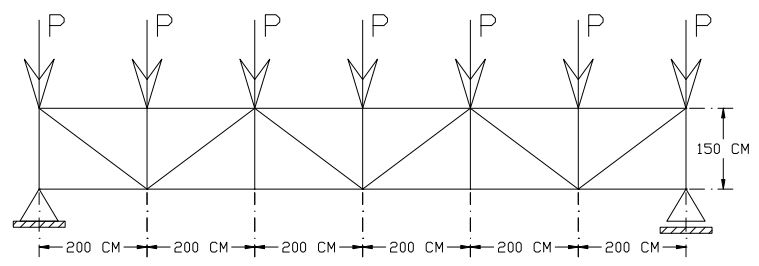


3. Rasuk N Terbalik:

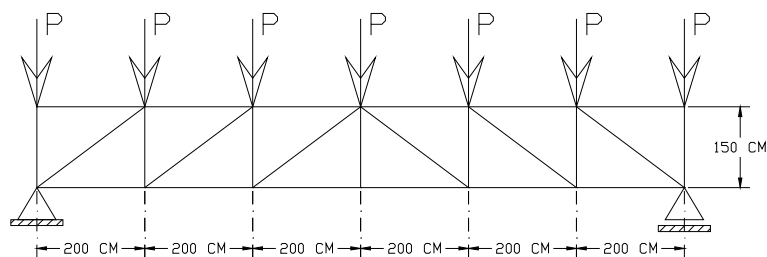

4. Rasuk N :

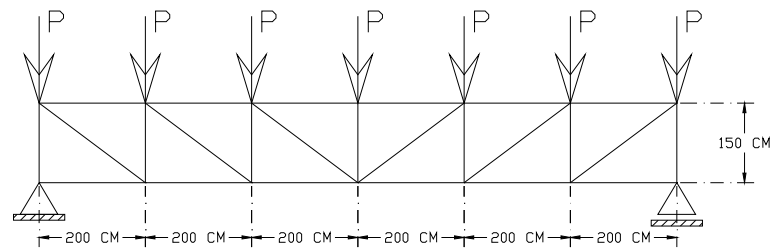

5. Rasuk X

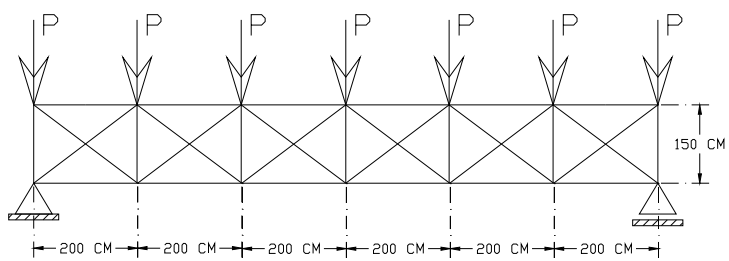

\section{Kemiringan Rangka Batang}

Kemiringan Rangka Batang dalam kajian ini sebagai berikut :

1. Kemiringan $0^{\circ}$

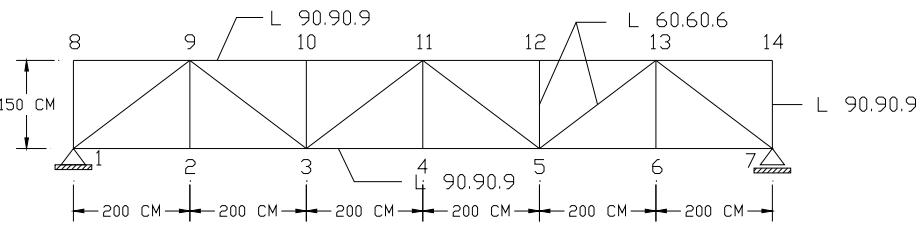

2. Kemiringan $5^{\circ}$

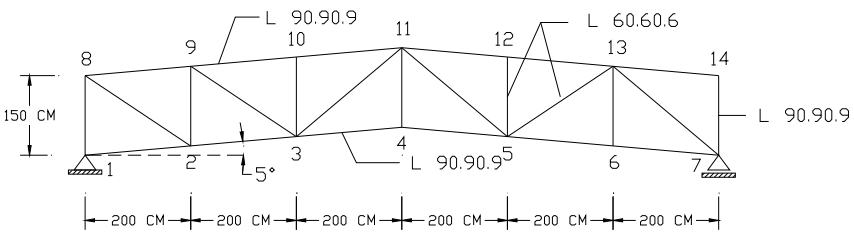

3. Kemiringan $15^{\circ}$

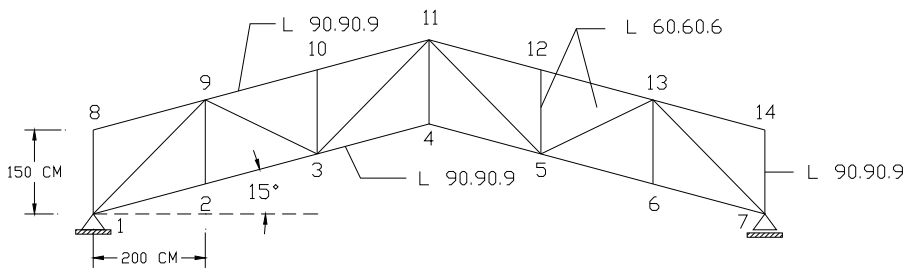


4. Kemiringan $30^{\circ}$

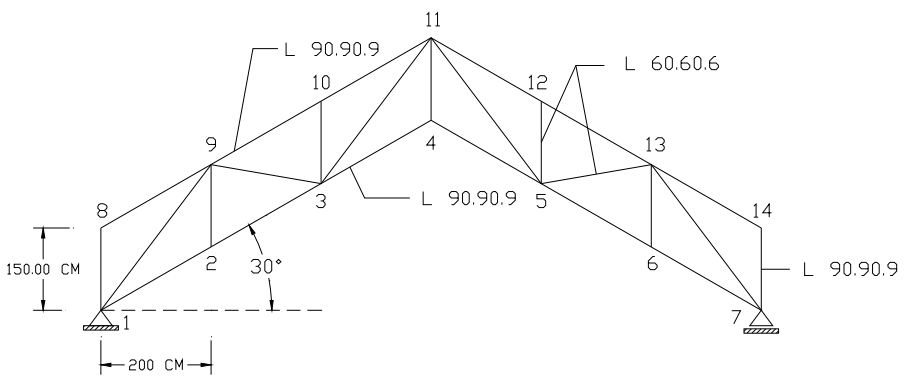

5. Kemiringan $45^{\circ}$

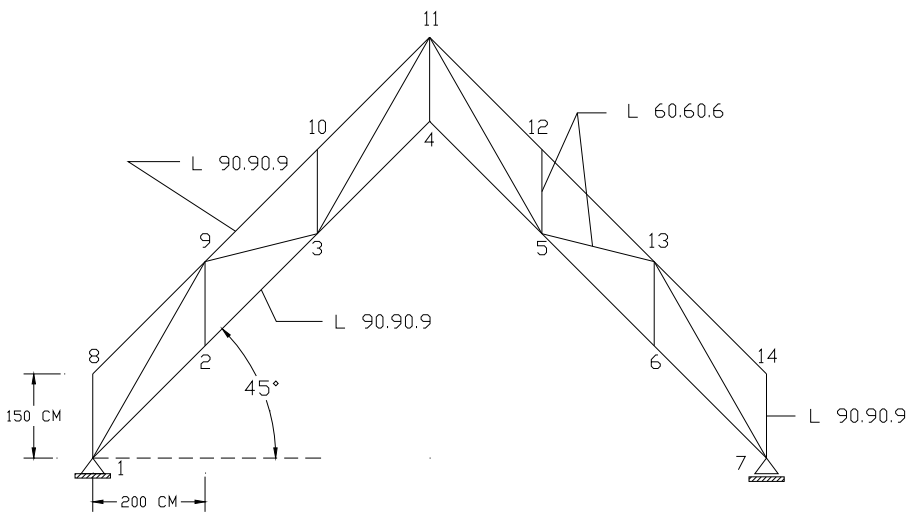

\section{Kombinasi Pembebanan}

Kombinasi Pembebanan dalam kajian diambil sebagai berikut :

DL berat sendiri Rangka Batang dan LL beban terpusat sebesar 2000 Kg ditempatkan pada titik buhul atas.

Kombinasi 1 : $1 \mathrm{DL}+1 \mathrm{LL}$

Kombinasi 2 : 1 LL

\section{PEMBAHASAN}

\section{Hasil Hitungan Akibat Beban Hidup}

\section{a. Model 1}

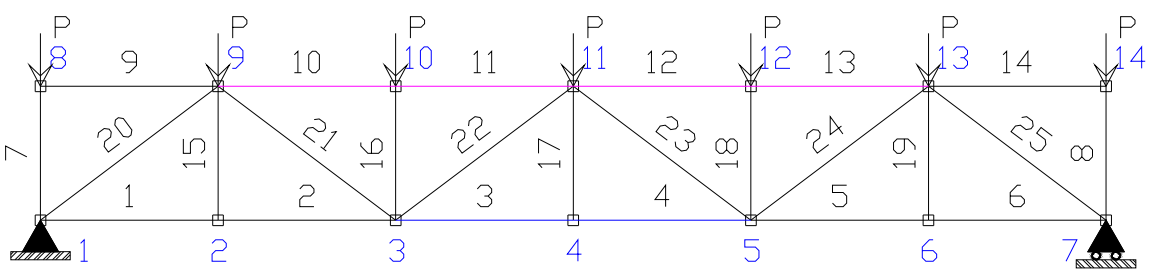


Tabel 1. Hasil perhitungan lendutan Model 1.

\begin{tabular}{|c|c|c|c|c|c|c|}
\hline \multirow{2}{*}{ No } & \multirow{2}{*}{ FILE } & \multirow{2}{*}{ SUDUT } & \multicolumn{4}{|c|}{ LENDUTAN ( CM ) } \\
\cline { 4 - 7 } & & & \multicolumn{4}{|c|}{ Kombinasi 2 1 LL } \\
\cline { 4 - 7 } & & & TITIK 4 & $\%$ & TITIK 11 & $\%$ \\
\hline 1 & MODEL 1 S 0 & $0^{\circ}$ & $-1,1844$ & 0,00 & $-1,1844$ & 0,00 \\
\hline 2 & MODEL 1 S 5 & $5^{\circ}$ & $-1,2448$ & 5,10 & $-1,2231$ & 3,27 \\
\hline 3 & MODEL 1 S 15 & $15^{\circ}$ & $-1,5019$ & 26,80 & $-1,4354$ & 21,19 \\
\hline 4 & MODEL 1 S 30 & $30^{\circ}$ & $-2,3866$ & 101,50 & $-2,2433$ & 89,40 \\
\hline 5 & MODEL 1 S 45 & $45^{\circ}$ & $-4,6566$ & 293,15 & $-4,4085$ & 272,20 \\
\hline & & & & & & \\
\hline
\end{tabular}

Hasil dari perhitungan model 1, lendutan yang terjadi pada titik 4 dengan kondisi datar mempunyai lendutan $=1,1844 \mathrm{~cm}$ dan bertambahnya kemiringan ternyata lendutan yang terjadi bertambah besar, kemiringan $45^{\circ}$ lendutannya $=4,6566 \mathrm{~cm}$.

\section{b. Model 2}

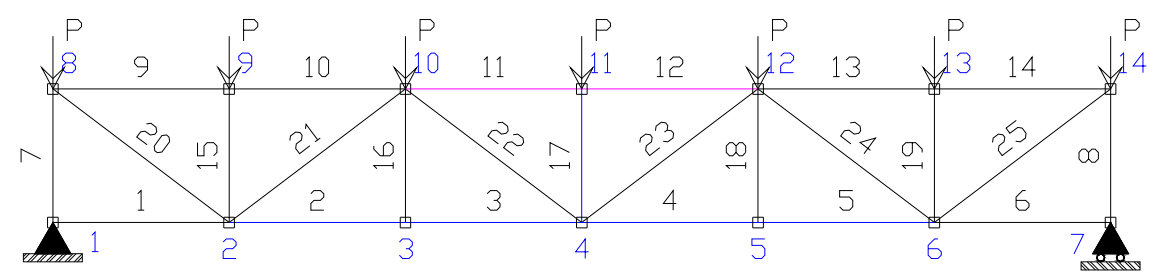

Tabel 2. Hasil perhitungan lendutan Model 2.

\begin{tabular}{|c|c|c|c|c|c|c|}
\hline \multirow{2}{*}{ No } & \multirow{2}{*}{ FILE } & \multirow{2}{*}{ SUDUT } & \multicolumn{4}{|c|}{ LENDUTAN ( CM ) } \\
\cline { 4 - 7 } & & & \multicolumn{4}{|c|}{ Kombinasi 2 : LL } \\
\cline { 4 - 7 } & & & TITIK 4 & $\%$ & TITIK 11 & $\%$ \\
\hline 1 & MODEL 2 S 0 & $0^{\circ}$ & $-1,2167$ & 0,00 & $-1,2374$ & 0,00 \\
\hline 2 & MODEL 2 S 5 & $5^{\circ}$ & $-1,2119$ & $-0,39$ & $-1,2109$ & $-3,28$ \\
\hline 3 & MODEL 2 S 15 & $15^{\circ}$ & $-1,3324$ & 9,51 & $-1,2866$ & 6,10 \\
\hline 4 & MODEL 2 S 30 & $30^{\circ}$ & $-1,9672$ & 61,69 & $-1,8446$ & 75,14 \\
\hline 5 & MODEL 2 S 45 & $45^{\circ}$ & $-3,8366$ & 215,34 & $-3,6092$ & 293,48 \\
\hline & & & & & & \\
\hline
\end{tabular}

Hasil dari perhitungan model 2, lendutan yang terjadi pada titik 4 dengan kondisi datar mempunyai lendutan $=1,2167 \mathrm{~cm}$, pada saat kemiringan $5^{\circ}$ lendutan mengecil menjadi $=1,2119 \mathrm{~cm}$ dan bertambahnya kemiringan 
ternyata lendutan yang terjadi bertambah besar, kemiringan $45^{\circ}$ lendutannya $=3,8366 \mathrm{~cm}$.

\section{c. Model 3}

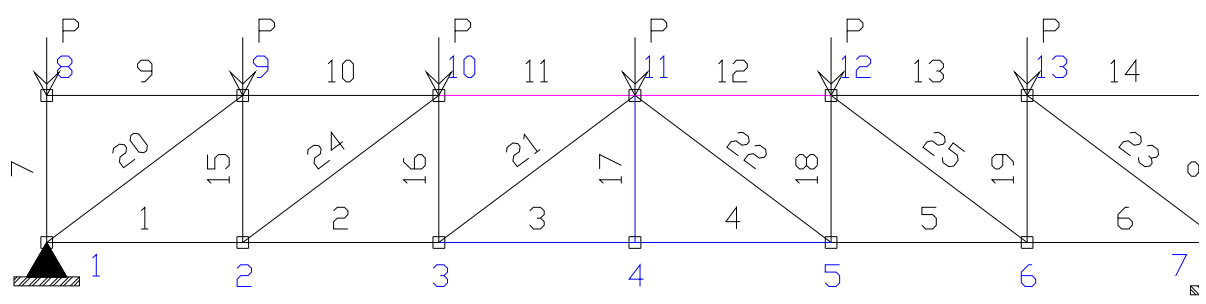

Tabel 3. Hasil perhitungan lendutan Model 3.

\begin{tabular}{|c|c|c|c|c|c|c|}
\hline \multirow{3}{*}{ No } & \multirow{3}{*}{ FILE } & \multirow{3}{*}{ SUDUT } & \multicolumn{4}{|c|}{ LENDUTAN ( CM) } \\
\hline & & & \multicolumn{4}{|c|}{ Kombinasi $2: 1 \mathrm{LL}$} \\
\hline & & & TITIK 4 & $\%$ & TITIK 11 & $\%$ \\
\hline 1 & MODEL 3 SO & $0^{\circ}$ & $-1,2258$ & 0,00 & $-1,2258$ & 0,00 \\
\hline 2 & MODEL $3 S 5$ & $5^{\circ}$ & $-1,3224$ & 7,89 & $-1,3007$ & 9,19 \\
\hline 3 & MODEL $3 S 15$ & $15^{\circ}$ & $-1,6563$ & 35,12 & $-1,5898$ & 44,62 \\
\hline 4 & MODEL 3 S 30 & $30^{\circ}$ & $-2,6886$ & 119,34 & $-2,5453$ & 161,75 \\
\hline 5 & MODEL 3 S 45 & $45^{\circ}$ & $-5,2193$ & 325,80 & $-4,9712$ & 459,10 \\
\hline
\end{tabular}

Hasil dari perhitungan model 3, lendutan yang terjadi pada titik 4 dengan kondisi datar mempunyai lendutan $=1,2258 \mathrm{~cm}$ dan bertambahnya kemiringan ternyata lendutan yang terjadi bertambah besar, kemiringan $45^{\circ}$ lendutannya $=5,2193 \mathrm{~cm}$.

\section{d. Model 4}

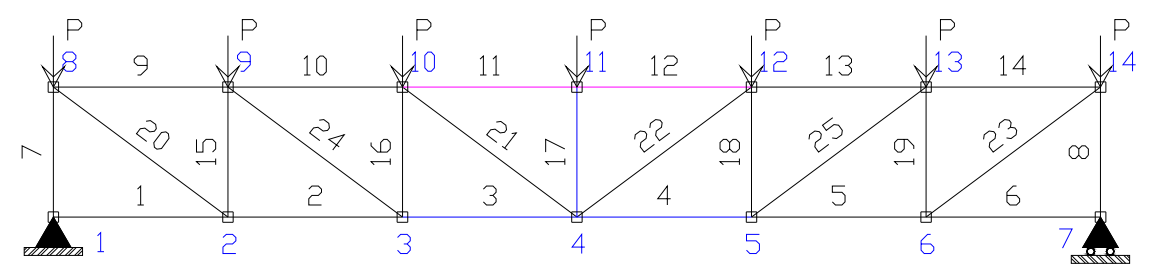


Tabel 4. Hasil perhitungan lendutan Model 4.

\begin{tabular}{|c|c|c|c|c|c|c|}
\hline \multirow{2}{*}{ NO } & \multirow{2}{*}{ FILE } & \multirow{2}{*}{ SUDUT } & \multicolumn{4}{|c|}{ LENDUTAN ( CM ) } \\
\cline { 4 - 7 } & & & \multicolumn{4}{|c|}{ Kombinasi 2 : 1 LL } \\
\cline { 4 - 7 } & & & TITIK 4 & $\%$ & TITIK 11 & $\%$ \\
\hline 1 & MODEL 4 S 0 & $0^{\circ}$ & $-1,2994$ & 0,00 & $-1,3200$ & 0,00 \\
\hline 2 & MODEL 4 S 5 & $5^{\circ}$ & $-1,2583$ & $-3,16$ & $-1,2573$ & $-8,28$ \\
\hline 3 & MODEL 4 S 15 & $15^{\circ}$ & $-1,3021$ & 0,21 & $-1,2563$ & $-8,42$ \\
\hline 4 & MODEL 4 S 30 & $30^{\circ}$ & $-1,7892$ & 37,70 & $-1,6666$ & 45,75 \\
\hline 5 & MODEL 4 S 45 & $45^{\circ}$ & $-3,3979$ & 161,51 & $-3,1705$ & 244,27 \\
\hline & & & & & & \\
\hline
\end{tabular}

Hasil dari perhitungan model 4, lendutan yang terjadi pada titik 4 dengan kondisi datar mempunyai lendutan $=1,2994 \mathrm{~cm}$, pada saat kemiringan $5^{\circ}$ lendutan mengecil menjadi $=1,2583 \mathrm{~cm}$ dan bertambahnya kemiringan ternyata lendutan yang terjadi bertambah besar, kemiringan $45^{\circ}$ lendutannya $=3,3979 \mathrm{~cm}$.

\section{e. Model 5}

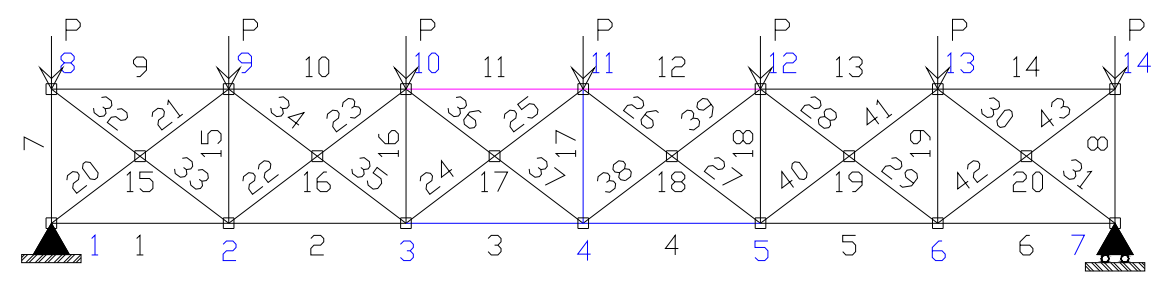

Tabel 4. Hasil perhitungan lendutan Model 4.

\begin{tabular}{|c|c|c|c|c|c|c|}
\hline \multirow{2}{*}{ No } & \multirow{2}{*}{ FILE } & \multirow{2}{*}{ SUDUT } & \multicolumn{4}{|c|}{ LENDUTAN ( CM ) } \\
\cline { 4 - 7 } & & & \multicolumn{4}{|c|}{ Kombinasi 2 : 1 LL } \\
\cline { 4 - 7 } & & & TITIK 4 & $\%$ & TITIK 11 & $\%$ \\
\hline 1 & MODEL5 S 0 & $0^{\circ}$ & $-0,9259$ & 0,00 & $-0,9336$ & 0,00 \\
\hline 2 & MODEL5 S 5 & $5^{\circ}$ & $-0,9492$ & 2,51 & $-0,9388$ & 0,49 \\
\hline 3 & MODEL 5 S 15 & $15^{\circ}$ & $-1,0854$ & 17,23 & $-1,0374$ & 9,69 \\
\hline 4 & MODEL 5 S 30 & $30^{\circ}$ & $-1,6383$ & 76,93 & $-1,5218$ & 54,91 \\
\hline 5 & MODEL 5 S 45 & $45^{\circ}$ & $-3,2414$ & 250,06 & $-3,0235$ & 195,11 \\
\hline & & & & & & \\
\hline
\end{tabular}

Hasil dari perhitungan model 5, lendutan yang terjadi pada titik 4 dengan kondisi datar mempunyai lendutan $=0,9259 \mathrm{~cm}$ dan bertambahnya 
kemiringan ternyata lendutan yang terjadi bertambah besar, kemiringan $45^{\circ}$ lendutannya $=3,2414 \mathrm{~cm}$.

\section{Hasil Hitungan Model 1,2,3,4 Dan 5 Akibat Beban Hidup dengan kemiringan}

Tabel 5. Hasil Perhitungan Lendutan Di Tengah Bentang

Akibat Beban Hidup.

\begin{tabular}{|c|c|c|c|c|c|c|}
\hline \multirow{2}{*}{ NO } & \multirow{2}{*}{$\begin{array}{c}\text { SUDUT } \\
(*)\end{array}$} & \multicolumn{5}{|c|}{ LENDUTAN ( CM ) } \\
\cline { 3 - 7 } & & \multicolumn{5}{|c|}{ Kombinasi 2 : 1 LL } \\
\hline & & MITIK 4 & TITIK 4 & TITIK 4 & TITIK 4 & TITIK 4 \\
\hline & 0 & 1,1844 & 1,2167 & 1,2258 & 1,2994 & 0,9259 \\
\hline 1 & 5 & 1,2448 & 1,2119 & 1,3224 & 1,2583 & 0,9492 \\
\hline 2 & 15 & 1,5019 & 1,3324 & 1,6563 & 1,3021 & 1,0854 \\
\hline 3 & 15 & MODEL 2 & MODEL 3 & MODEL 4 & MODEL 5 \\
\hline 4 & 30 & 2,3866 & 1,9672 & 2,6886 & 1,7892 & 1,6383 \\
\hline 5 & 45 & 4,6566 & 3,8366 & 5,2193 & 3,3979 & 3,2414 \\
\hline & & & & & & \\
\hline & & TITIK 11 & TITIK 11 & TITIK 11 & TITIK 11 & TITIK 11 \\
\hline & & MODEL 1 & MODEL 2 & MODEL 3 & MODEL 4 & MODEL 5 \\
\hline 1 & 0 & 1,1844 & 1,2374 & 1,2258 & 1,3200 & 0,9336 \\
\hline 2 & 5 & 1,2231 & 1,2109 & 1,3007 & 1,2573 & 0,9388 \\
\hline 3 & 15 & 1,4354 & 1,2866 & 1,5898 & 1,2563 & 1,0374 \\
\hline 4 & 30 & 2,2433 & 1,8446 & 2,5453 & 1,6666 & 1,5218 \\
\hline 5 & 45 & 4,4085 & 3,6092 & 4,9712 & 3,1705 & 3,0235 \\
\hline & & & & & & \\
\hline
\end{tabular}

Hasil dari perhitungan, lendutan yang terjadi pada titik 4 dengan kondisi datar maupun dengan kemiringan, lendutan yang paling kecil adalah model $5=0,9259 \mathrm{~cm}$, pada saat kemiringan $5^{\circ}$ lendutan yang mengecil adalah model $2=1,2119 \mathrm{~cm}$, kondisi datar $=1,2167 \mathrm{~cm}$ dan model $4=1,2583 \mathrm{~cm}$, kondisi datar $=1,2994 \mathrm{~cm}$ 


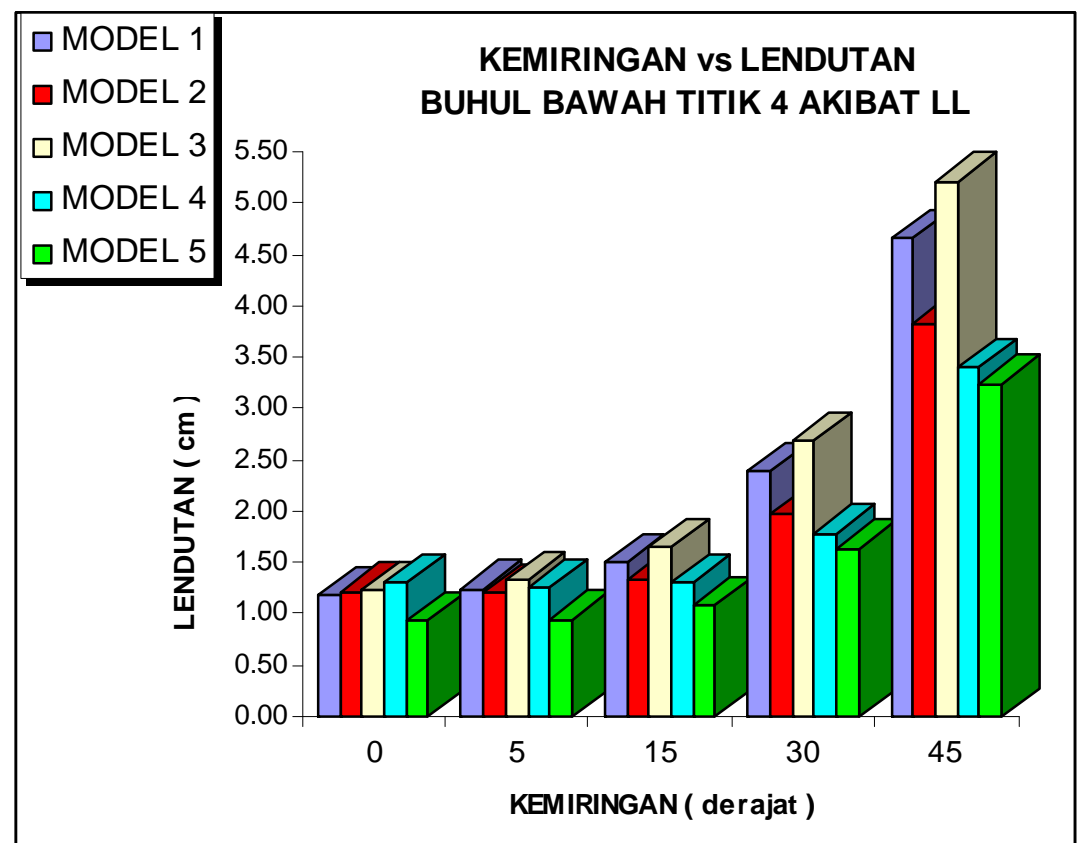

Gambar 4.1 Grafik Kemiringan Rangka Terhadap Lendutan Di Tengah Bentang Pada Titik 4 Buhul Bawah Akibat Beban Hidup

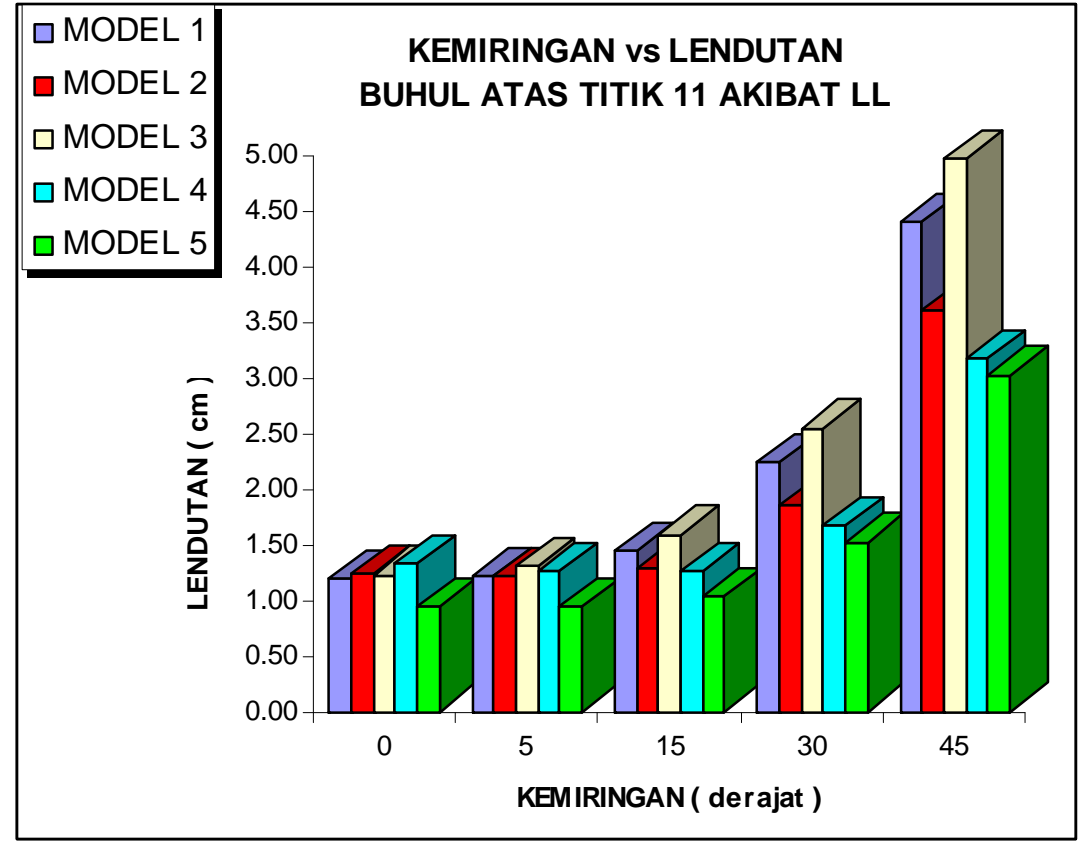

Gambar 4.2 Grafik Kemiringan Rangka Terhadap Lendutan Di Tengah Bentang Pada Titik 11 Buhul Atas Akibat Beban Hidup 


\section{KESIMPULAN}

1. Untuk kondisi datar maupun kondisi miring, lendutan yang paling kecil adalah bentuk rangka model 5 .

2. Untuk kondisi kemiringan sekitar $5^{\circ}$ bentuk rangka yang paling baik adalah model 2 dan model 4 karena lendutan yang terjadi lebih kecil dari kondisi datar.

3. Lendutan pada rangka batang ternyata tidak mengikuti fungsi momen, karena ada pengaruh perpendekan atau perpanjangan batang serta pengaruh putaran sudut titik pertemuan antar batang.

\section{DAFTAR PUSTAKA}

1. Chu Kia Wang, (1952), ”Statically Indeterminate Structures”,McGrawHill Kogakusha, LTD.

2. Soemono, ( 1980), "Statika 2 - Bangunan Rangka Batang”, ITB Bandung. 